\title{
A Comparative Study of Diesel Oil and Soybean Oil as Oil-Based Drilling Mud
}

\author{
Okorie E. Agwu, Anietie N. Okon, and Francis D. Udoh \\ Department of Chemical \& Petroleum Engineering, Faculty of Engineering, University of Uyo, PMB 1017, Uyo, \\ Akwa Ibom State 52001, Nigeria \\ Correspondence should be addressed to Anietie N. Okon; anietieokon@uniuyo.edu.ng
}

Received 20 July 2014; Accepted 21 January 2015

Academic Editor: Guillaume Galliero

Copyright (c) 2015 Okorie E. Agwu et al. This is an open access article distributed under the Creative Commons Attribution License, which permits unrestricted use, distribution, and reproduction in any medium, provided the original work is properly cited.

Oil-based mud (OBM) was formulated with soybean oil extracted from soybean using the Soxhlet extraction method. The formulated soybean mud properties were compared with diesel oil mud properties. The compared properties were rheological properties, yield point and gel strength, and mud density and filtration loss properties, fluid loss and filter cake. The results obtained show that the soybean oil mud exhibited Bingham plastic rheological model with applicable (low) yield point and gel strength when compared with the diesel oil mud. The mud density measurement showed that soybean OBM was slightly higher than diesel OBM with mud density values of $8.10 \mathrm{lb} / \mathrm{gal}$ and $7.98 \mathrm{lb} /$ gal, respectively, at barite content of $10 \mathrm{~g}$. Additionally, the filtration loss test results showed that soybean mud fluid loss volumes, water and oil, were $13 \mathrm{~mL}$ and $10 \mathrm{~mL}$, respectively, compared to diesel oil mud volume of $15 \mathrm{~mL}$ and $12 \mathrm{~mL}$. Furthermore, the filtration loss test indicated that the soybean oil mud with filter cake thickness of $2 \mathrm{~mm}$ had a cake characteristic of thin and soft while the diesel oil mud resulted in filter cake thickness of $2.5 \mathrm{~mm}$ with cake characteristic of firm and rubbery. In comparison with previous published works in the literature, the soybean oil mud exhibits superior rheological and filtration property over other vegetable oil-based muds. Therefore, the formulated soybean oil mud exhibited good drilling mud properties that would compare favourably with those of diesel oil muds. Its filter cake characteristic of thin and soft is desirable and significant to avert stuck pipe during drilling operations, meaning that an oil-based drilling mud could be formulated from soybean oil.

\section{Introduction}

The need to drill a usable hole with minimal environmental impact and with a low cost imprint has been a dream long held by drillers and industry operators alike. One major component of the oil well drilling operation which is often referred to as "the blood of the drilling process" is the drilling fluid. It is the "architect" which can make the drilling operation either materialize or unrealizable. This is because the fluid plays a number of invaluable roles. These roles include but are not limited to transporting the drill cuttings from the bottom of the hole to the surface, cooling and lubricating the drilling bit as well as the drill string to minimize its wear, sealing off permeable formations by forming an impermeable, relatively thin mud cake at the borehole wall of the permeable formations, creating an overbalanced drilling condition to control the formation pressure, hold drill cuttings in suspension when circulation is interrupted, creating a buoyancy force to partly support the weight of the drill string and casing string, reduction of formation damage of various horizons penetrated, transmission of hydraulic horsepower to the bit and allowing maximum penetration rates, carrying downhole information from the drilled well in form of signals to the surface for interpretation, and so forth. Therefore, the success of any rotary drilling operation is hinged on the performance of the drilling fluid used for the drilling operation. In turn, the performance of these drilling fluids is dependent on the rheological properties of the mud used. These rheological properties include plastic viscosity, yield point, and gel strength, among others. Drilling fluid costs are estimated to gulp about $20 \%$ of the total drilling cost of a well [1]. As explorationists make discoveries in unconventional terrains such as deep water offshore fields, ultra high temperature, high pressure fields, arctic regions, and other hostile environments, the cost of drilling for oil and gas reserves becomes more expensive. From a drilling 
fluids perspective, the demands of intrinsic to deep-water drilling and completions are especially acute as operators must reconcile performance and economic objectives with unique technical and environmental obstacles [2]. These drilling environments require fluids that excel in performance. Therefore, measuring fluid performance requires the evaluation of all key drilling parameters and their associated cost [3]. Over time, the oil well drilling industry has basically made use of two types of drilling fluids, namely, water-based muds (WBMs) and oil-based drilling muds (OBMs). On the one hand, due to the lower costs and ease of formulation, water-based mud is most commonly used as drilling fluid. On the other hand, the oil-based muds despite being more costly when compared with their water based counterparts are used because of their good rheological characteristics at temperatures as high as $500^{\circ} \mathrm{F}$ exhibiting better stability behaviour, their effectiveness against all types of corrosion, and superior lubricating characteristics. Oil-based muds have the additional advantage of being able to drill through formations containing water swellable clays. To formulate these oil-based muds, diesel oil is used as the base fluid primarily because of its viscosity characteristics, low flammability, and low solvency for rubber [4]. All such petroleum-based oils used for drilling mud contain relatively large amounts of aromatics and at least a substantial concentration of n-olefins both of which may be harmful or toxic to animal and plant life [5]. As such, the drilling industry has over time developed variant forms of oil-based muds which are technically called synthetic-based muds (SBMs). An SBM was used for the first time to drill a well in the Norwegian Sector of the North Sea in 1990. The first well drilled with an SBM in the UK Sector was in 1991 and in the Gulf of Mexico in 1992 [6, 7]. These SBMs combine the desirable operating qualities of the oilbased mud and lower the toxicity and environmental impact qualities of the water-based mud. In this paper, two oil-based muds are formulated and compared; one is formulated with diesel oil and the other from soybean oil. The basis for the comparison stems from the rheological properties and the filtration characteristics of the drilling muds.

\section{Materials and Methods}

2.1. Sample Preparation. The soybean seeds were collected from a local market in Uyo, Akwa Ibom State, a state in the southern part of Nigeria. The outer skin was first removed and then it was ground using a manual grinding machine, before finally extracting oil from them. The method used in extracting oil from the seeds was the solvent extraction method. This method involves extracting oil from oil-bearing materials by treating it with a low boiling point solvent. This method was preferred to all other extraction methods (such as expellers and hydraulic presses) because it recovers almost all the oil and leaves behind only $0.5 \%$ to $0.7 \%$ residual oil in the raw material $[8,9]$. Ten $(10) \mathrm{kg}$ of ground soybean seeds were measured out, tied in a filter paper, and loaded into the extraction chamber of the Soxhlet extractor. About $500 \mathrm{~mL}$ of $\mathrm{n}$-Hexane was poured into the round bottom flask (i.e., the boiling flask) contained in the heating mantle of the system, and the heating mantle was turned on and allowed to heat at $60^{\circ} \mathrm{C}$. The solvent was heated to reflux and the solvent vapour moved up the distillation arm and entered into the condenser which condenses the vapour. At this point, the condensed vapour dripped back down into the extraction chamber housing the samples. Then at a certain level, the siphon emptied the liquid in the extraction chamber into the boiling flask. This cycle continued until the liquid in the flask changed colour (yellow in this case) to a considerable extent. At this point, the fluid mixture (n-hexane and soya oil) was collected in a glass beaker and was separated using a steam bath. The steaming was done at $60^{\circ} \mathrm{C}$; the hexane evaporated while the extracted oil remained in the beaker and was collected and stored. This process was repeated until enough quantity of the soybean oil was obtained for the mud formulation.

2.2. Physicochemical Properties of the Oil-Based Fluids. The fluids used as base-fluid in the formulation of the OBM were analyzed to determine its physiochemical properties. By knowing these parameters, an early description of mud composition and behaviour is estimated. Therefore, the parameters that were tested include the following.

(a) Specific gravity: it shows the weight of base-fluid. This will indicate the density of developed mud.

(b) Pour point: it shows the lowest temperature at which the base-fluid will be able to flow.

(c) Flash point: it shows the temperature at which the fluid begins to burn.

(d) Kinematic viscosity: it shows the resistance of base fluid to flow under the influence gravity force.

(e) Cloud point: this is the temperature at which dissolved solids are no longer completely soluble, precipitating as a second phase giving the fluid a cloudy appearance.

Interestingly, some research work has been done by researchers to determine the aforementioned base fluid properties. Table 1 presents the physiochemical properties of diesel oil and soybean oils.

2.3. Chemical Stability of Soybean Oil and Diesel Oil. Aside from knowing the physiochemical properties of the soybean oil, the knowledge of its chemical stability at wellbore condition (high temperature) becomes paramount for its use as base fluid in OBMs formulation. According to Wikipedia (online), a chemical substance is said to be "stable" if it is not particularly reactive in the environment or during normal use and retains its useful properties on the timescale of its expected usefulness. In particular, the usefulness is retained in the presence of air, moisture, or heat and under the expected conditions of application. In this direction, the biodegradability provides an indication of the persistence of any particular substance in the environment and is the yardstick for assessing the eco friendliness of substances [13]. So many studies by researchers have shown unanimity as to the biodegradable nature of soybean oil and other vegetable oils as compared to diesel oil. For instance, Howell [14] 
TABLE 1: Physicochemical properties of diesel and soybean oil.

\begin{tabular}{|c|c|c|}
\hline Property & Diesel oil \# 2 & Soybean oil \\
\hline Physical form & Liquid & Liquid \\
\hline Melting point & $-30^{\circ} \mathrm{C}$ to $-18^{\circ} \mathrm{C}^{\mathrm{a}}$ & $-16^{\circ} \mathrm{C}^{\mathrm{b}}$ \\
\hline Boiling point & $282^{\circ} \mathrm{C}-338^{\circ} \mathrm{C}^{\mathrm{a}}$ & $257^{\circ} \mathrm{C}^{\mathrm{d}}$ \\
\hline Density & $830 \mathrm{~kg} / \mathrm{m}^{3}$ at $20^{\circ} \mathrm{C}^{\mathrm{c}}$ & $920 \mathrm{~kg} / \mathrm{m}^{3}$ at $20^{\circ} \mathrm{C}^{\mathrm{c}}$ \\
\hline Water solubility & Immiscible & Immiscible \\
\hline Flash point & $70^{\circ} \mathrm{C}^{\mathrm{c}}$ & $330^{\circ} \mathrm{C}^{\mathrm{c}}$ \\
\hline Cloud point & $-9^{\circ} \mathrm{C}^{\mathrm{c}}$ & $-4^{\circ} \mathrm{C}^{\mathrm{c}}$ \\
\hline Kinematic Viscosity & 6 Cst at $20^{\circ} \mathrm{C}^{\mathrm{c}}$ & $61 \mathrm{Cst}$ at $20^{\circ} \mathrm{C}^{\mathrm{c}}$ \\
\hline Pour point & $-18^{\circ} \mathrm{C}^{\mathrm{c}}$ & $-20^{\circ} \mathrm{C}^{\mathrm{c}}$ \\
\hline
\end{tabular}

Source:

${ }^{\mathrm{a}} \mathrm{http}: / /$ www.inchem.org.

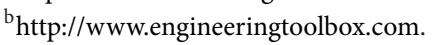

${ }^{c} \mathrm{http}: / /$ www.proceedings.scielo.br/img/eventos/agrener/n4v1/064t01.gif.

${ }^{\mathrm{d}}$ http://van.physics.illinois.edu/qa/listing.php?id=1428.

TABLE 2: Base properties of oil for use as OBMs.

\begin{tabular}{|c|c|c|c|c|c|c|}
\hline Property & Aniline point $\left({ }^{\circ} \mathrm{C}\right)$ & Pour point $\left({ }^{\circ} \mathrm{C}\right)$ & Flash point $\left({ }^{\circ} \mathrm{C}\right)$ & Fire point $\left({ }^{\circ} \mathrm{C}\right)$ & $\begin{array}{c}\text { Kinematic } \\
\text { viscosity at } 40^{\circ} \mathrm{C} \text {, Cst }\end{array}$ & $\begin{array}{c}\text { Aromatic } \\
\text { content }(\%)\end{array}$ \\
\hline $\begin{array}{l}\text { Base oil required } \\
\text { properties }\end{array}$ & $>65$ & $<$ Ambient temperature & $>66$ & $>80$ & $2.3-3.5$ & $4-8$ \\
\hline Diesel oil & 145 & -18 & 66 & 108 & $2.7-3.4$ & $25 \% \mathrm{v} / \mathrm{v}$ \\
\hline Soybean oil & 60 & -20 & 330 & 342 & 31.8 & N/A \\
\hline
\end{tabular}

Source: Yassin et al., 1991 [10].

and Erhan and Perez [15] all agree that soybean oil and other vegetable oils are environmentally friendly, renewable, nontoxic, and biodegradable. To further buttress the benefits of soybean oil as a viable alternative to the use of diesel oil in OBM formulation from the chemical stability standpoint, Table 2 presents some of the properties for this assertion. The table presents the base oil requirements for use as oil base in OBMs formulation. In comparison, diesel oil exhibits high volatilities with low flash points which may lead to safety hazards compared to soybean oil with high flash point and low volatility. Thus, diesel oil when used as OBMs would jeopardize the health and safety of its users and the environment as well.

In addition, the pour and fire points of diesel oil compared to that of soybean oil imply that the former would be chemically unstable at extreme temperatures (i.e., low and high), as diesel oil flow rate at $-18^{\circ} \mathrm{C}$ becomes difficult. Also, in high temperature-high pressure (HTHP) well, diesel oil with fire point of $108^{\circ} \mathrm{C}$ will ignite, thus making its use as base fluid in OBMs detrimental. However, the only drawback for the soybean oil is the low aniline point which could be detrimental to rubber elements on the drilling rig.

2.4. Mud Formulation. Formulations of oil-based mud with some additives were performed in this study. The following additives were used for the developed oil-based muds: primary and secondary emulsifier (GLO PEMUL 1000 and GLO SEMUL 1000, resp.), filtration control additive (hydroxy ethyl cellulose), viscosifier (bentonite), weighting material (barite), and caustic soda $(\mathrm{NaOH})$ along with $(\mathrm{pH}$ enhancer). For comparison, diesel oil and soybean oil were used to formulate oil-based drilling fluid using same formulation specifications based on API (American Petroleum Institute) standard of $25 \mathrm{~g}$ bentonite to $350 \mathrm{~mL}$ base fluid for nontreated bentonite. Thus, the mud samples were formulated based on the concept of maintaining the same component proportions in each fluid. The oil-water ratio used in formulating the mud was 70 to 30 . The mixing order used during the formulation of the two muds is presented in Table 3. The formulated drilling muds were allowed to age for 24 hours before testing for their various mud properties. Thereafter, barite content of $10 \mathrm{~g}$ was added to the formulated muds to observe their mud density behaviour to barite content.

\subsection{Mud Properties Determination}

2.5.1. Rheological Properties Measurement. The Fann V-G viscometer was used to determine the rheological properties of the mud samples. The equipment was switched on and allowed to stabilize, after which the viscosity of distilled water was tested to check the integrity of the equipment. The mud sample was poured into the cup of the viscometer and was placed on the viscometer stand. The stand was adjusted and held in position as the rotor sleeve was immersed in the mud exactly to the fill line. The speed selector knob was selected to rotate at $600 \mathrm{rpm}$ (revolutions per minute), and the power was switched on. When a steady dial reading was reached, this was recorded as the 600 RPM dial reading. The above process was repeated for $300,200,100,6$, and $3 \mathrm{rpms}$. The rheogram (shear stress-shear rate profile) for the readings is 
TABLE 3: Composition of soybean oil and diesel oil mud.

\begin{tabular}{lcccc}
\hline Mud component & Diesel oil \# & Soybean oil & Mixing duration (mins) & Mixing order \\
\hline Oil $(\mathrm{mL})$ & 245 & 245 & 5 & 1 \\
Primary emulsifier $(\mathrm{mL})$ & 6 & 6 & 5 & 2 \\
Secondary emulsifier $(\mathrm{mL})$ & 4 & 4 & 5 & 3 \\
Filter loss agent HEC $(\mathrm{g})$ & 0.35 & 0.35 & 15 & 4 \\
Water $(\mathrm{mL})$ & 105 & 105 & 5 & 5 \\
Bentonite $(\mathrm{g})$ & 25 & 25 & 5 & 7 \\
NaOH $(\mathrm{g})$ & 0.25 & 0.25 & 10 & 8 \\
Barite $(\mathrm{g})$ & 10 & 10 & 5 \\
\hline
\end{tabular}

TABLE 4: Viscometer readings of the formulated mud samples.

\begin{tabular}{|c|c|c|c|c|}
\hline \multirow{2}{*}{ Viscometer speed (rpm) } & \multicolumn{2}{|c|}{ Diesel oil } & \multicolumn{2}{|c|}{ Soybean oil } \\
\hline & Dial reading & Shear stress $\left(\mathrm{lb} / 100 \mathrm{ft}^{2}\right)$ & Dial reading & Shear stress $\left(\mathrm{lb} / 100 \mathrm{ft}^{2}\right)$ \\
\hline 600 & 51 & 54.06 & 38 & 40.28 \\
\hline 300 & 35 & 37.1 & 24 & 25.44 \\
\hline 200 & 27 & 28.62 & 16 & 16.96 \\
\hline 100 & 18 & 19.08 & 9 & 9.54 \\
\hline 6 & 9 & 9.54 & 3 & 3.18 \\
\hline 3 & 7 & 7.42 & 2.3 & 2.438 \\
\hline
\end{tabular}

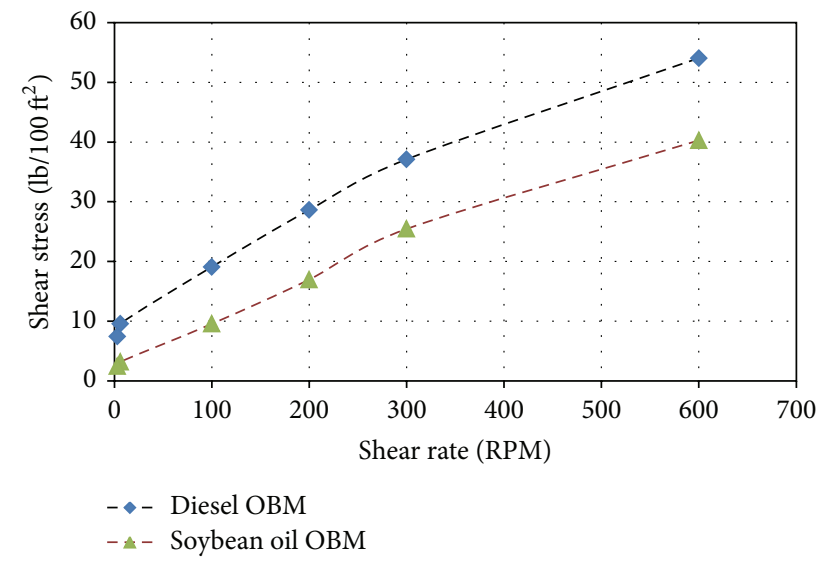

FIGURE 1: Shear stress-shear rate profile.

presented in Figure 1. Consequently, the apparent viscosity $(\mathrm{AV})$, plastic viscosity (PV), and yield point (YP) of the mud samples (presented in Table 5) were calculated based on two data point approach from the viscometer (Fann V-G) dial readings presented in Table 4 using

$$
\begin{aligned}
& \mathrm{PV}=\theta_{600}-\theta_{300} \\
& \mathrm{YP}=\theta_{300}-\mathrm{PV}, \\
& \mathrm{AV}=\frac{1}{2} * \theta_{600},
\end{aligned}
$$

where $\mathrm{AV}$ is apparent viscosity, $\mathrm{PV}$ is plastic viscosity, $\theta_{600}$ is dial reading at 600 revolutions per minute, $\theta_{300}$ is dial reading at 300 revolutions per minute, and YP is yield point.

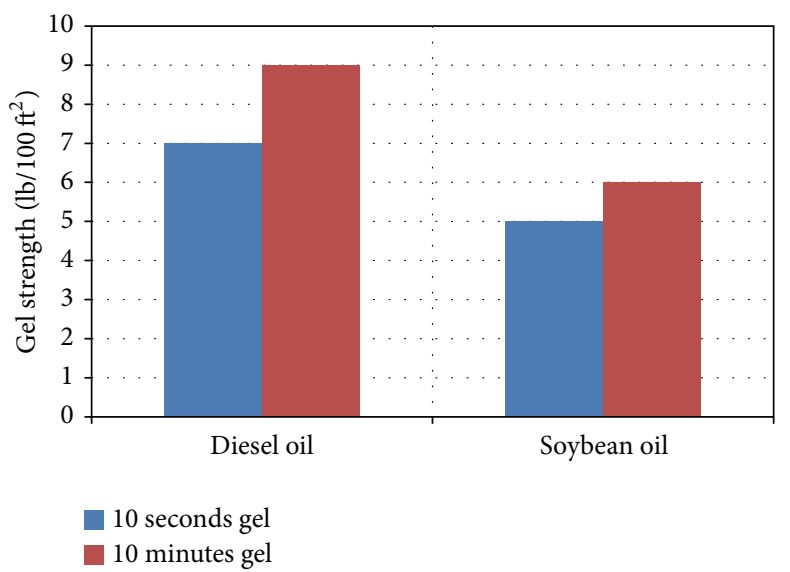

FIGURE 2: Gel strength of diesel oil and soybean oil OBMs.

The gel strength of the mud samples were also determined using the Fann V-G viscometer. The speed selector knob was rotated to stir the mud sample for ten seconds, and then it was rotated at $3 \mathrm{rpm}$ and the power was immediately shut off. As soon as the sleeve stopped rotating, the power was turned on after 10 seconds and 10 minutes, respectively, at $3 \mathrm{rpm}$. The maximum dial was recorded for each case as the gel strength of the mud samples at $10 \mathrm{sec}$ and $10 \mathrm{~min}$. Thus, the results are presented in Table 5 and Figure 2.

2.5.2. Mud Density Measurement. A mud balance was used to determine the mud density. The mud balance was calibrated by using it to test for the density of water before testing for the densities of the mud samples. The mud balance cup was filled to the top with the mud samples. The lid was placed on the cup and was turned to ensure that it was firmly put in place. 
TABLE 5: Mud rheological parameters value.

\begin{tabular}{lcc}
\hline Mud properties & Diesel oil & Soybean oil \\
\hline Gel strength $10 \mathrm{sec}, \mathrm{lb} / 100 \mathrm{ft}^{2}$ & 7 & 5 \\
Gel strength $10 \mathrm{~min}, \mathrm{lb} / 100 \mathrm{ft}^{2}$ & 9 & 6 \\
Plastic viscosity, cp & 16 & 14 \\
Yield point, $\mathrm{lb} / 100 \mathrm{ft}^{2}$ & 20 & 11 \\
Apparent viscosity, cp & 25.5 & 19 \\
\hline
\end{tabular}

TABLE 6: Mud density values with barite content.

\begin{tabular}{lcc}
\hline Barite (g) & \multicolumn{2}{c}{ Mud density (lb/gal) } \\
\hline 0 & Diesel oil & Soybean oil \\
10 & 7.50 & 7.82 \\
\hline
\end{tabular}

Excess mud spilled through the vent was wiped off from the lid. The balance was placed on a knife edge and the rider was moved along the graduated arm until the cup and the arm were balanced as indicated by the bubble. The mud weight in pounds per gallon $(\mathrm{lb} / \mathrm{gal})$ was read at the edge of the rider towards the mud cup as indicated by the arrow on the rider and recorded. The muds' density without barite content and with barite content of $10 \mathrm{~g}$ were measured and recorded as presented in Table 6.

2.5.3. Mud Filtration Properties Measurement. The filtration test was performed using standard cell at API condition of $100 \mathrm{psi}$ differential pressure at room temperature. The filter press used for the tests consisted of six independent filter cells mounted on a common frame (as shown in Figure 8(b)) after which the mud to be tested was introduced into the cup assembly. With the air pressure valve closed, the mud cup assembly was clamped to the frame while holding the filtrate outlet end finger tight. A graduated cylinder was placed underneath to collect filtrate, after which the pressure valve was opened for gas to flow in from an air compressor pump and the timing was started at the same time. After 30 minutes the pressure valve was shut and the filtrate collected in the graduated cylinder (in $\mathrm{mL}$ ) and the filter cake (in $\mathrm{mm}$ ) were measured and recorded. The results of the test are presented in Table 7 and Figures 3 and 4.

Additionally, calculation of filtrate loss at variable time intervals relative to known filtrate loss and time interval can be predicted using the expanded equation

$$
f_{1}=f \times\left(\frac{\sqrt{T_{1}}}{\sqrt{T}}\right)
$$

where $f$ is known filtrate at a time interval of $T$ and $f_{1}$ is unknown filtrate at a time interval of $T_{1}$.

Therefore, the calculated values for filtration volume at times of $1,5,7.5,10$, and 15 minutes are presented in Table 8 and depicted in Figures 5 and 6 . In addition, the spurt loss
TABLE 7: Mud filtration loss results.

\begin{tabular}{lcc}
\hline Filtrate properties & Diesel OBM & Soybean OBM \\
\hline Total fluid volume $(\mathrm{mL})$ & 27 & 23 \\
Oil volume $(\mathrm{mL})$ & 12 & 10 \\
Water volume $(\mathrm{mL})$ & 15 & 13 \\
Cake thickness $(\mathrm{mm})$ & 2.5 & 2.0 \\
\hline
\end{tabular}

TABLE 8: Calculated mud filtration.

\begin{tabular}{lcccccc}
\hline & \multicolumn{6}{c}{ Time (minutes) } \\
Mud type & 1 & 5 & 7.5 & 10 & 15 & 30 \\
& \multicolumn{7}{c}{ Filtrate volume (mL) } \\
\hline Diesel OBM & 4.93 & 11.02 & 13.5 & 15.58 & 19.09 & 27 \\
Soybean oil OBM & 4.20 & 9.39 & 11.5 & 13.27 & 16.26 & 23 \\
\hline
\end{tabular}

(initial loss) volume from the formulated mud was estimated using the expanded equation

$$
V_{\text {sp }}=V_{1.0}-\left[\frac{V_{7.5}-V_{1.0}}{\sqrt{7.5}-\sqrt{1}}\right] \sqrt{1},
$$

where $V_{\mathrm{sp}}$ is spurt loss volume, $V_{1.0}$ is filtrate volume obtained at time of one (1) minute, and $V_{7.5}$ is filtrate volume obtained at time interval of 7.5 minutes.

\section{Discussion of Results}

3.1. Rheological Properties. The fundamental reason for choosing to study the rheological properties, plastic viscosity, yield point, and gel strength, as well as the filtration properties, fluid loss and filter cake of both oils as the basis for comparison, is the relevance these properties offer to the overall drilling mud performance. The yield point (YP) is used to evaluate the ability of a mud to lift cuttings out of the annulus. A high YP implies a non-Newtonian fluid; one that carries cuttings better than a fluid of similar density but lower YP. Additionally, frictional pressure loss is directly related to the YP. It is important to state here that excessively high YP leads to high pressure losses while the drilling mud is being circulated. The viscometer speeds and dial readings were converted to shear rate and shear stress, respectively. Figure 1 presents the shear stress-shear rate profile (rheogram) of the formulated mud from the values obtained. This figure depicts the rheological model of the two mud samples. As shown in the figure, the rheology of both mud samples is similar (i.e., increasing from left to right with intercept on the vertical axis). This indicates that the mud samples are similar in their rheological behavior. In this connection, it can be seen that the two formulated OBMs exhibit a rheological model which is almost similar to the Bingham plastic model. A Bingham plastic fluid will not flow until the shear stress $(\tau)$ exceeds a certain minimum value known as the yield point, YP [4]. After the yield point (YP) has been exceeded, the changes in shear stress are proportional to changes in shear rate in which the constant of proportionality is known as the plastic viscosity (PV). From Figure 1, diesel OBM has a higher plastic viscosity compared to soybean OBM. This indicates that 


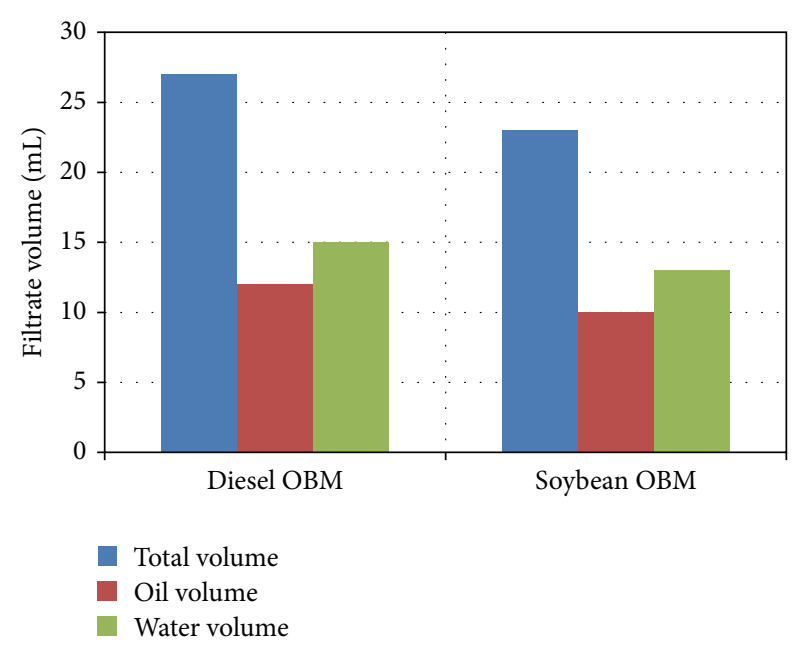

FIgURE 3: Filtration volume plot for diesel and soybean OBMs.

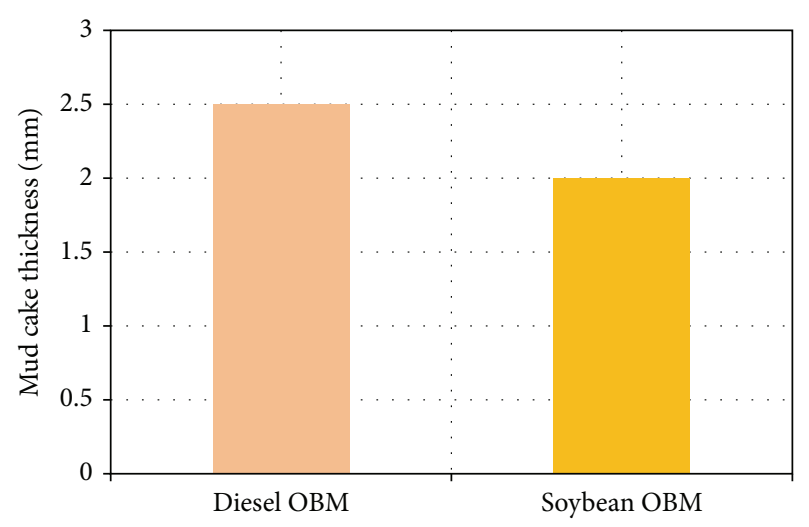

Figure 4: Comparison of mud cake thickness.

diesel OBM has a higher viscosity, which would offer a greater resistance to fluid flow that will result in increased circulating pressures that can cause loss of circulation and increased pumping costs. Thus, soybean OBM with low viscosity is a good prospect for drilling in the sense that its low viscosity will offer less resistance to fluid flow and therefore would lead to a turbulent flow at low pump pressure which would result in good hole cleaning.

The gel strength is another important drilling fluid property, as it demonstrates the ability of the drilling mud to suspend drill solid (drilled cuttings) and weighting material when mud circulation is ceased. Figure 2 depicts the gel strength of the formulated diesel and soybean OBMs. The figure and Table 4 indicate that soybean OBM has low gel strength values at both 10 seconds and 10 minutes compared to diesel OBM. Thus, the gel strength values of the soybean oil-based mud show that the mud exhibits a flat gel structure, meaning that the mud will remain pumpable with time if left static in the hole. Conversely, the gel strength values of the diesel oil-based mud at 10-minute gel value were much higher than the 10-second gel value, indicating that the diesel mud exhibits a progressive gel structure. This is an indication that the gelation of the diesel mud is rapidly gaining strength

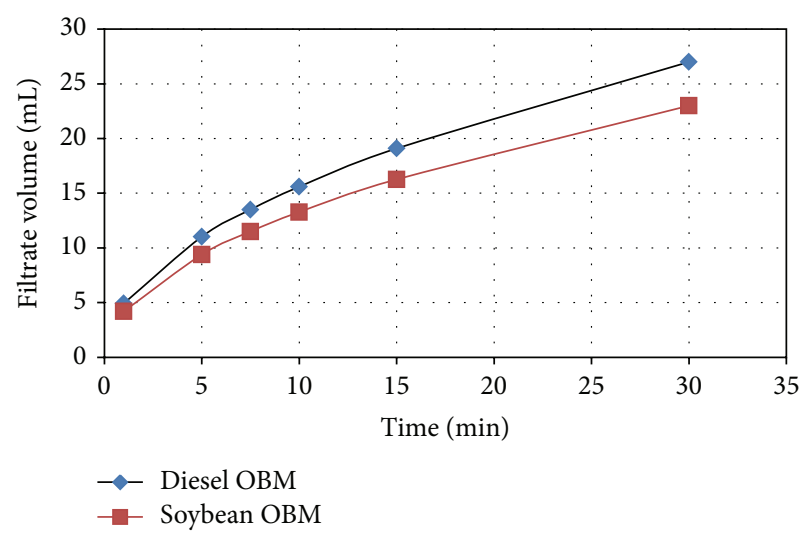

Figure 5: Comparison of filtrate loss with time.

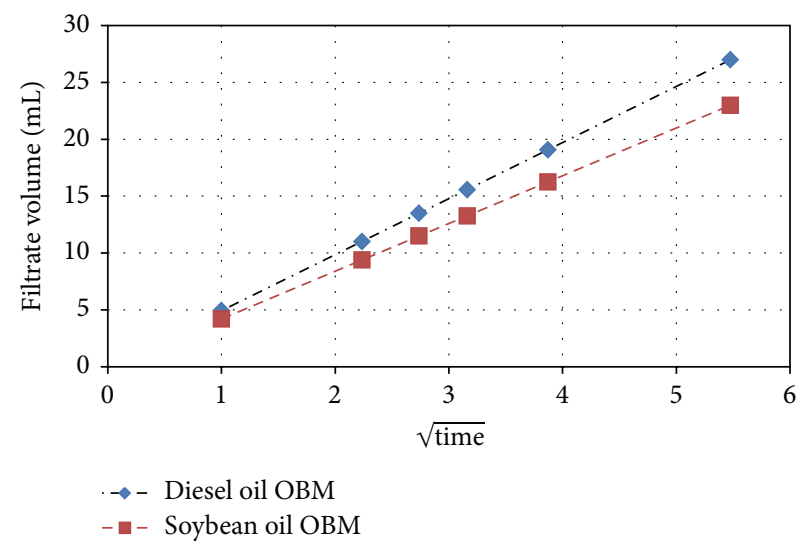

FIGURE 6: Comparison of filtrate volume versus square root of time.

with time, which generally is an undesirable feature of a drilling mud. Therefore, the weak gel/fragile property of the soybean OBM is desirable during drilling operation as the gel can be broken easily with lower pump pressure to make circulation. On the other hand, the high value of diesel OBM gel strength would lead to high circulation breakdown pressure and increased pumping costs as high pump power is required to overcome this gelling potential of diesel OBM.

3.2. Mud Density. Mud density of drilling fluid system is mainly necessary for the control of formation pressures. Additionally, an increase in mud density increases the capacity of the mud to carry drilled cuttings as the suspending fluid has an associated buoyancy effect on the cuttings. As presented in Table 6, soybean mud without barite content has higher mud density $(7.82 \mathrm{lb} / \mathrm{gal})$ than diesel mud $(7.50 \mathrm{lb} / \mathrm{gal})$, an indication owing to the soybean oil density $\left(920 \mathrm{~kg} / \mathrm{m}^{3}\right.$ about $7.66 \mathrm{lb} / \mathrm{gal}$ ) as presented in Table 1 . Table 6 further depicts the mud's density variation at $10 \mathrm{~g}$ barite content. From the table, the formulated soybean OBM has higher density value than diesel OBM. The results indicate an increase in soybean mud density to $8.10 \mathrm{lb} / \mathrm{gal}$ and diesel mud density to $7.98 \mathrm{lb} / \mathrm{gal}$ at $10 \mathrm{~g}$ barite content. These results indicate an increase of $3.58 \%$ and $6.40 \%$ for soybean and diesel OBMs' density, respectively. This assertion indicates 
TABle 9: Previous works (Adesina et al. $[8,9]$ ) mud properties.

\begin{tabular}{|c|c|c|c|c|c|}
\hline Mud properties & Diesel oil & Canola oil & Jatropha oil & Algae oil & Moringa oil \\
\hline Density, lb/gal & 8.26 & 8.47 & 8.32 & 7.81 & 8.30 \\
\hline $\mathrm{pH}$ & 8.00 & 9.50 & 9.00 & 9.00 & 9.00 \\
\hline \multicolumn{6}{|c|}{ Rheological properties } \\
\hline Plastic viscosity, $\mathrm{cP}$ & 13.0 & 12.0 & 8.0 & 8.0 & 11.0 \\
\hline Apparent viscosity, cP & 92.5 & 64.0 & 77.0 & 61.0 & 84.5 \\
\hline Yield point, $\mathrm{lb} / 100 \mathrm{ft}^{2}$ & 155 & 112 & 112 & 106 & 147 \\
\hline Gel strength, lb/100 $\mathrm{ft}^{2}$ & $50 / 51$ & $60 / 72$ & $54 / 55$ & $52 / 43$ & $52 / 53$ \\
\hline \multicolumn{6}{|c|}{ Filtration property } \\
\hline Total fluid volume, $\mathrm{mL}$ & 6.90 & 6.00 & 6.30 & 6.20 & 7.20 \\
\hline Oil volume, $\mathrm{mL}$ & 2.30 & 1.00 & 1.10 & 1.10 & 2.50 \\
\hline Water volume, $\mathrm{mL}$ & 4.60 & 5.00 & 5.20 & 5.10 & 4.70 \\
\hline Cake thickness, mm & 1.00 & 0.90 & 0.89 & 0.90 & 0.90 \\
\hline
\end{tabular}

Source: Adesina et al., $2012[8,9]$.

that soybean OBMs density can be increased with barite to suit any drilling operation especially when it is required that a high mud weight is necessary. A move that is very significant in the event of hole drilling problems and when gas cut mud is encountered.

3.3. Filtration Loss. Filtration rate is often the most important property of a drilling fluid, particularly when drilling permeable formations where the hydrostatic pressure exceeds the formation pressure. Proper control of filtration can prevent or minimize wall sticking and drag and in some areas improve borehole stability. Figure 3 and Table 7 show filtrate volume from the formulated OBMs collected after 30 minutes. The results depict that the water volume collected from diesel mud $15 \mathrm{~mL}$ was higher than the soybean mud volume of $13 \mathrm{~mL}$. This could be attributed to the fact that the water may not have been completely emulsified in the diesel mud, thereby forming an unstable emulsion. However, the volumes of oil collected from both samples were $12 \mathrm{~mL}$ and $10 \mathrm{~mL}$ for diesel and soybean mud, respectively. Additionally, Figure 5 shows the calculated filtrate loss volumes for time interval of 1.0, 5.0, $7.5,10.0,15.0$, and 30.0 minutes. The figure indicates that the filter loss values increased with time, as the diesel OBM shows high filter loss capacities compared to the soybean OBM. Figure 6 presents the filtrate volumes against the square root of the time in minutes. This move was to ascertain the spurt loss of the formulated OBMs. Thus, the spurt loss values obtained for the two mud samples were, however, the same with spurt loss volume of about $0.01 \mathrm{~mL}$.

3.4. Mud Cake Thickness. As earlier alluded to the diesel OBM has a higher filtration rate than the formulated soybean OBMs. Generally, high filtrate volumes are associated with thick filter cake because the cake is formed by deposition of clay particles on the walls of the hole during filtrate loss to the formation. So the higher the filter volume, the thicker the filter cake and the less efficient the drilling mud. In view of its high filtration rate, diesel OBM has a thicker mud cake $(2.5 \mathrm{~mm})$ than soybean OBM $(2.0 \mathrm{~mm})$ as presented in Figure 4 . The effect of this is that a thick mud cake reduces the effective diameter of the drilled wellbore thereby increasing

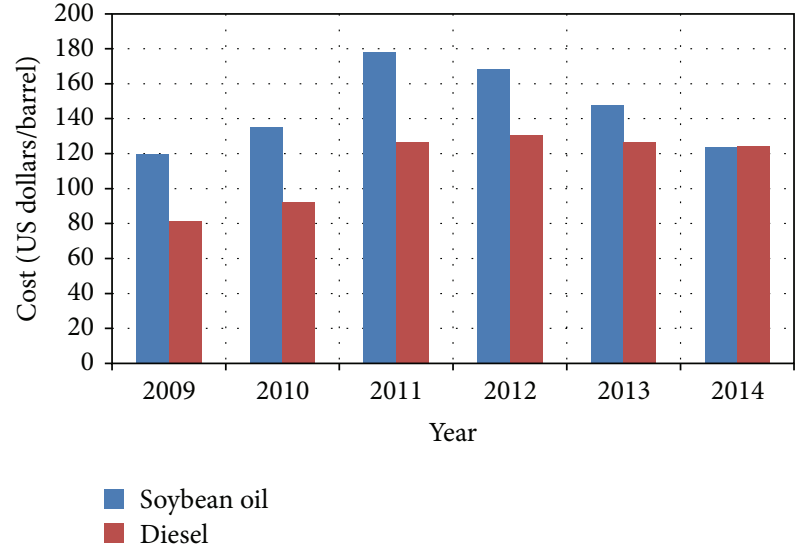

FIGURE 7: Trend of price of soybean oil and diesel oil in the last six years.

the area of contact between the drill pipe and the cake leading to increased risk of stuck pipe incidents. Based on this result, therefore, the formulated soybean OBM has good filtration properties that will be effective for drilling purposes as it would prevent stuck pipe incidents. In addition, diesel OBM filter cake has a firm and rubbery physical characteristic while the soybean OBM has a soft physical characteristic as indicated in Figure 8(d). On this note, the thin but soft mud cake obtained in the case of the soybean oil OBM is desirable during drilling operations.

3.5. Comparison of Soybean Oil Mud with Previous Works on Other Oil Base Fluids. In the literature, limited or no direct comparison of the rheological properties of soybean oil with other vegetable oils as base fluid in oil-based drilling mud formulation is available. However, the literature presents the comparison of different vegetable oil as alternative to diesel oil in oil-based mud formulation. Flowing from this, Adesina et al. $[8,9]$ presented algae, moringa, canola, and jatropha oils as alternative to diesel oil in oil-based mud formulation. Their study as presented in Table 9 revealed the following mud properties for the various oils they studied. 


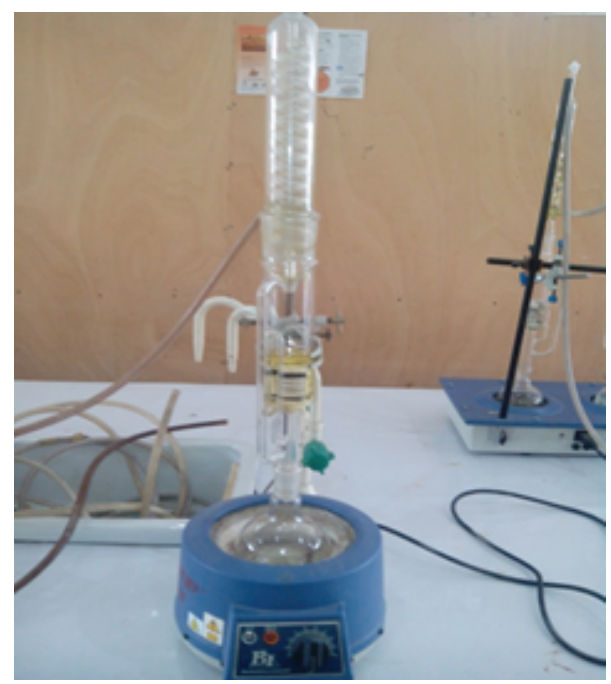

(a) Soxhlet extractor

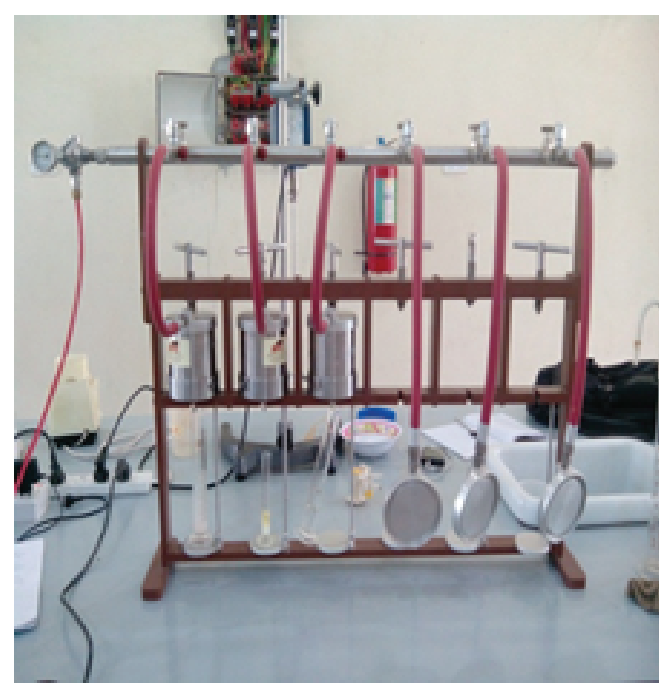

(b) API Filter press

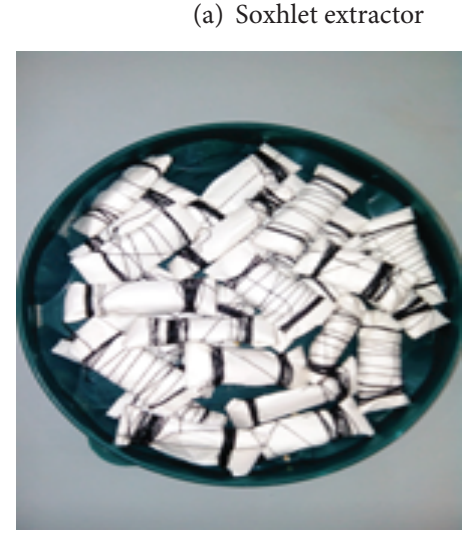

(c) Ground soybean in API filter paper

FIGURE 8: Equipment and materials used during test.
Furthermore, Paul et al. [11] evaluated the viability of jatropha and groundnut oils as alternative to diesel oil in oil-based drilling mud formulation. The obtained mud properties from their study are shown in Table 10.

Additionally, Akintola et al. [12] examined the use of locally sourced oil: groundnut oil, melon oil, vegetable oil, soya bean oil, and palm oil as substitute for diesel oil in formulating oil base drilling fluids. Their work focused on evaluating the filtration property of the aforementioned oils and comparing the result with formulated diesel oil mud's filtration property. The $\mathrm{pH}$ and filtration test result as obtained from their study is presented in Table 11.

Actually, the yardstick of comparison of the previously published works on various vegetable oil with the soybean oil as base fluid in mud formulation becomes worrisome, as various authors used different mud formulation standards: API and OCMA standard. Adesina et al. [8,9] did not state their drilling mud formulation standard whereas Paul et al. [11] used API standard of $20 \mathrm{~g}$ bentonite to $350 \mathrm{~mL}$ liquid phase: oil-water ratio of $70: 30$, with addition of $106 \mathrm{~g}$ of weighting material (barite) to the formulated mud. Also, Akintola et al. [12] used $350 \mathrm{~mL}$ continuous phase of $70: 30$ oil-water ratio with unstated grams (g) of bentonite.
Table 10: Previous works (Paul et al. [11]) mud properties.

\begin{tabular}{lccc}
\hline Mud properties & $\begin{array}{c}\text { Diesel } \\
\text { oil }\end{array}$ & $\begin{array}{c}\text { Jatropha } \\
\text { oil }\end{array}$ & $\begin{array}{c}\text { Groundnut } \\
\text { oil }\end{array}$ \\
\hline Density, lb/gal & 7.5 & 8.5 & 7.9 \\
Plastic viscosity, cP & 8.0 & 15 & 35 \\
Apparent viscosity, cP & 25 & 55 & 42.5 \\
Yield point, lb/100 ft ${ }^{2}$ & 32 & 45 & 15 \\
Gel strength, lb/100 $\mathrm{ft}^{2}$ & $16 / 15$ & $8 / 10$ & $4 / 7$ \\
\hline
\end{tabular}

Source: Paul et al., 2014 [11].

Hence, aside from the addition of barite, Paul et al. [11] and this study used almost the same drilling mud formulation standard. Thence, the comparison of the various published work results, Tables 9 through 11, with this study results, Tables 5 and 7, indicates that favourable rheological and filtration properties would be achieved with soybean oil over jatropha, canola, and moringa oil, among others, as base fluid in oil-based drilling mud formulation. Owing to the fact that, the previously published vegetable oils resulted in high rheological properties, plastic viscosity, yield point, and gel 
TABle 11: Previous works (Akintola et al. [12]) mud properties.

\begin{tabular}{lcccccc}
\hline Mud properties & Diesel oil & Groundnut oil & Melon oil & Palm oil & Soya oil & Vegetable oil \\
\hline $\mathrm{pH}$ & 9.0 & 8.0 & 8.0 & 8.0 & 8.0 & 8.0 \\
Filtrate volume, $\mathrm{mL}$ & 14.5 & 12.5 & 15.0 & 11.0 & 13.5 & 15.0 \\
\hline
\end{tabular}

Source: Akintola et al., 2014 [12].

TABle 12: Price of soybean oil and diesel oil in the last six years.

\begin{tabular}{lcc}
\hline Year & Soybean oil $(\$ / \mathrm{bbl})$ & Diesel oil $(\$ / \mathrm{bbl})$ \\
\hline 2009 & 119.58 & 81.48 \\
2010 & 135.39 & 92.22 \\
2011 & 177.98 & 126.63 \\
2012 & 168.61 & 130.76 \\
2013 & 147.98 & 126.66 \\
2014 & 123.68 & 124.46 \\
\hline
\end{tabular}

Source: Index Mundi (online) Commodity prices. http://www.indexmundi .com/commodities/.

strength which will require high pump power to initiate mud circulation during drilling operation.

3.6. Cost Comparison of Soybean Oil and Diesel Oil. For every business venture, an economic analysis or a cost benefit analysis of the project to be undertaken is required. In the same vein, in carrying out a comparative study of the use of soybean oil as substitute for diesel oil in drilling mud formulation, it is imperative that the cost of these oils is factored into consideration. Thus, Table 12 and Figure 7 show the price of both oils in the last six years.

From the Table 12 and Figure 7, it is observed that the cost per barrel of soybean oil in the previous five years (i.e., 2009 through 2013) remained higher than that of the number 2 diesel oil. Interestingly, in 2014, the cost per barrel of soybean oil became slightly lower than diesel oil as its production increased. Although the high cost of soybean oil would definitely increase the cost of formulating OBMs with it, this high cost, however, would eventually be offset by the superior rheological properties of the soybean oil. Additionally, soybean oil is environmentally friendly (biodegradability) in terms of cuttings disposal and reduced liabilities in the event of spillage.

\section{Conclusion}

It is a well-known fact that the performance of drilling fluid during drilling operation is influenced by its properties such as mud viscosity, density, $\mathrm{pH}$, and filtration loss, among others. In this study, soybean oil was used as a base fluid in oil-based mud (OBM) formulation. The formulated soybean OBM properties were compared with diesel OBM. While the formulated soybean OBM has very good potentials as oil-based drilling mud when compared with diesel OBM, based on the results obtained from the study, the following conclusions can be drawn.

(i) The formulated soybean OBM has a Bingham plastic rheological model with low yield point and gel strength, mud property desirable for turbulent flow at low pump pressure for effective hole cleaning.

(ii) The soybean OBM has relatively high density and can be increased with densifiers to desirable values during equivalent circulating density (ECD) predictions in order to obtain a successful drilling operation.

(iii) The filtration loss property of the formulated soybean OBM compared favorably with diesel OBM with filter cake characteristic of thin and soft desired during drilling operations.

\section{Appendix}

See Figure 8.

\section{Conflict of Interests}

The Authors declare that there is no conflict of interests regarding the publication of the paper.

\section{References}

[1] Shell Petroleum Development Company, Shell Intensive Training Manual, Shell Petroleum Development Company, 2000.

[2] J. E. Friedheim, "Area-specific analysis reflects impact of new generation fluid systems on deepwater exploration," in Proceedings of the IADC/SPE Asia Pacific Drilling Technology Conference, IADC/SPE 47842, Society of Petroleum Engineers, Jakarta, Indonesia, September 1998.

[3] B. Hughes, Drilling Fluids Reference Manual, 2006.

[4] A. T. Bourgoyne, M. E. Chenevert, K. K. Millheim, and F. S. Young, Applied Drilling Engineering, vol. 2 of SPE Textbook Series, SPE, Richardson, Tex, USA, 2003.

[5] M. M. Dardira, S. Ibrahimea, M. Solimanb, S. D. Desoukya, and A. A. Hafiza, "Preparation and evaluation of some esteramides as synthetic based drilling fluids," Egypt Journal of Petroleum, vol. 23, no. 1, pp. 35-43, 2014.

[6] J. E. Friedheim and H. L. Conn, "Second generation synthetic fluids in the north sea: are they better?" in Proceedings of the SPE/IADC Drilling Conference, IADC/SPE 35061, pp. 215-228, Society of Petroleum Engineers, New Orleans, La, USA, March 1996.

[7] R. G. Fechhelm, B. J. Gallaway, and J. M. Farmer, "Deepwater sampling at a synthetic drilling mud discharge site on the outer continental shelf, Northern Gulf of Mexico," in Proceedings of the SPE/EPA Exploration and Production Environmental Conference, SPE 52744, pp. 509-513, Society of Petroleum Engineers, Austin, Tex, USA, February-March 1999.

[8] F. Adesina, A. Anthony, A. Gbadegesin, O. Eseoghene, and A. Oyakhire, "Environmental impact evaluation of a safe drilling mud," in Proceedings of the SPE Middle East Health, Safety, 
Security and Environment Conference, SPE 152865, pp. 2-4, Abu Dhabi, United Arab Emirates, April 2012.

[9] F. Adesina, F. Olugbenga, A. Churchill, A. Abiodun, and A. Anthony, "Novel formulation of environmentally friendly oil based drilling mud," in New Technologies in the Oil and Gas Industry, chapter 3, InTech, 2012.

[10] A. M. Yassin, A. Kamis, and M. O. Abdullah, "Palm oil diesel as a base fluid in formulating oil based drilling fluid," SPE Paper 23001, Society of Petroleum Engineers, 1991.

[11] A. L. A. Paul, V. E. Efeovbokhan, A. A. Ayoola, and O. A. Akpanobong, "Investigating alternatives to diesel in oil based drilling mud formulations used in the oil industry," Journal of Environment and Earth Science, vol. 4, no. 14, pp. 70-77, 2014.

[12] S. Akintola, A. B. Oriji, and M. Momodu, "Analysis of filtration properties of locally sourced base oil for the formulation of oil based drilling fluids," Scientia Africana, vol. 13, no. 1, pp. 171-177, 2014.

[13] E. O. Aluyor, K. O. Obahiagbon, and M. Ori-Jesu, "Biodegradation of vegetable oils: a review," Scientific Research and Essays, vol. 4, no. 6, pp. 543-548, 2009.

[14] S. Howell, Promising Industrial Applications for Soybean Oil in the US, American Soybean Association, National Biodiesel Board, 2007.

[15] S. Z. Erhan and J. M. Perez, Biobased Industrial Fluids and Lubricants, The American Oil Chemists' Society, 2002. 

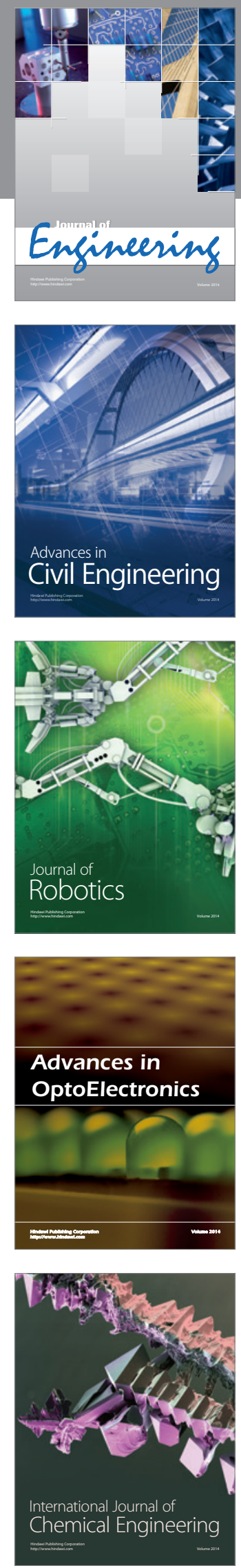

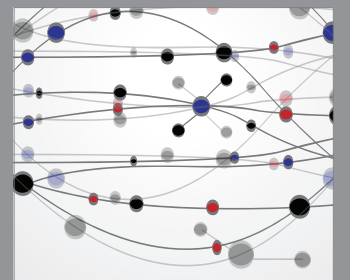

The Scientific World Journal
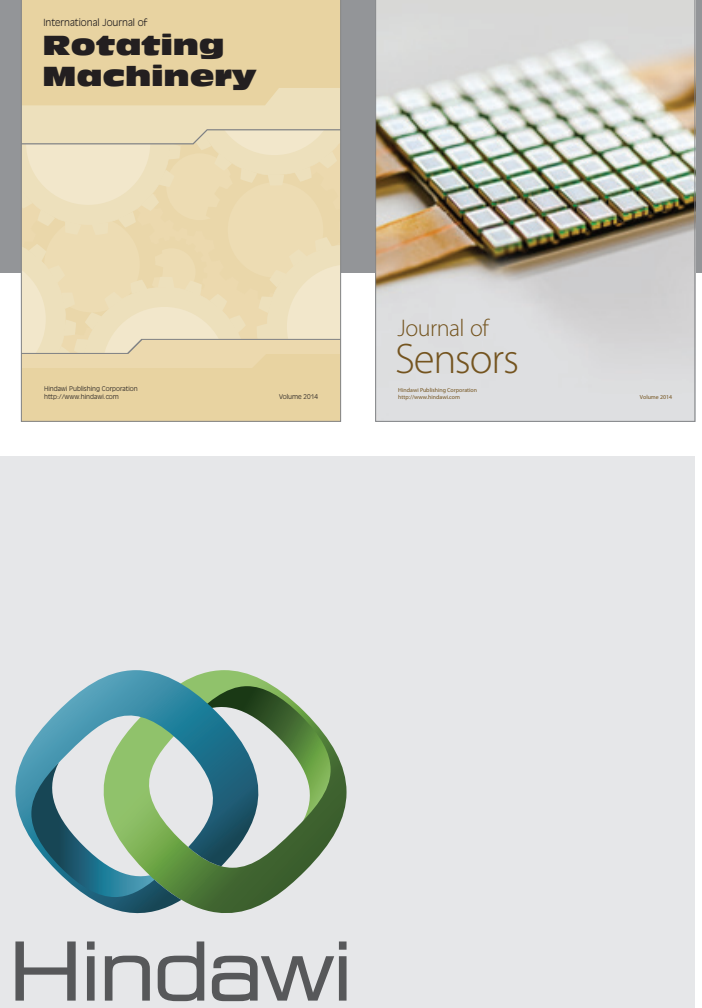

Submit your manuscripts at http://www.hindawi.com
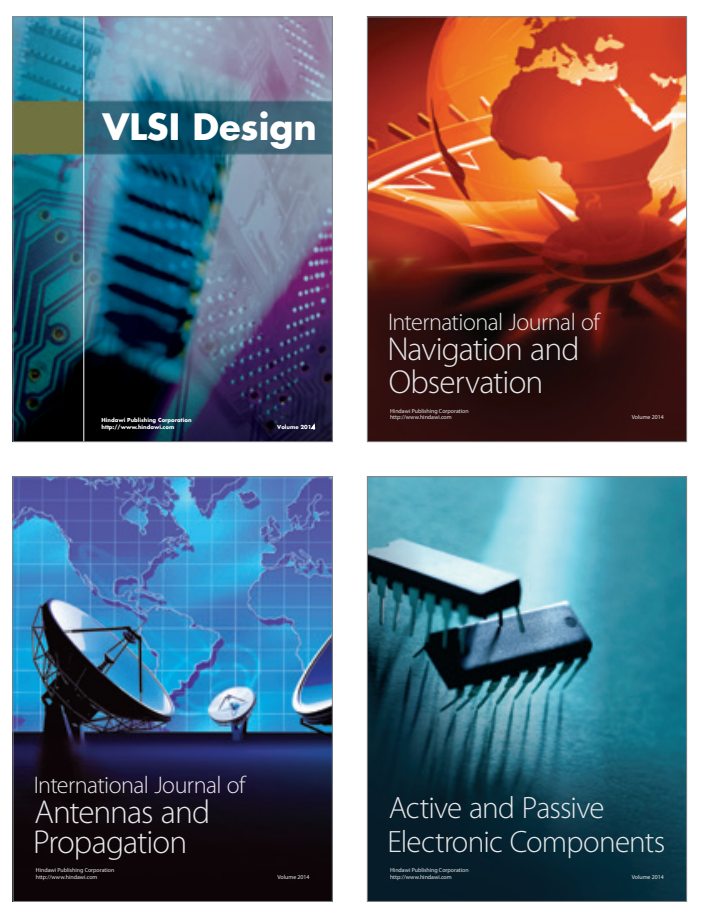
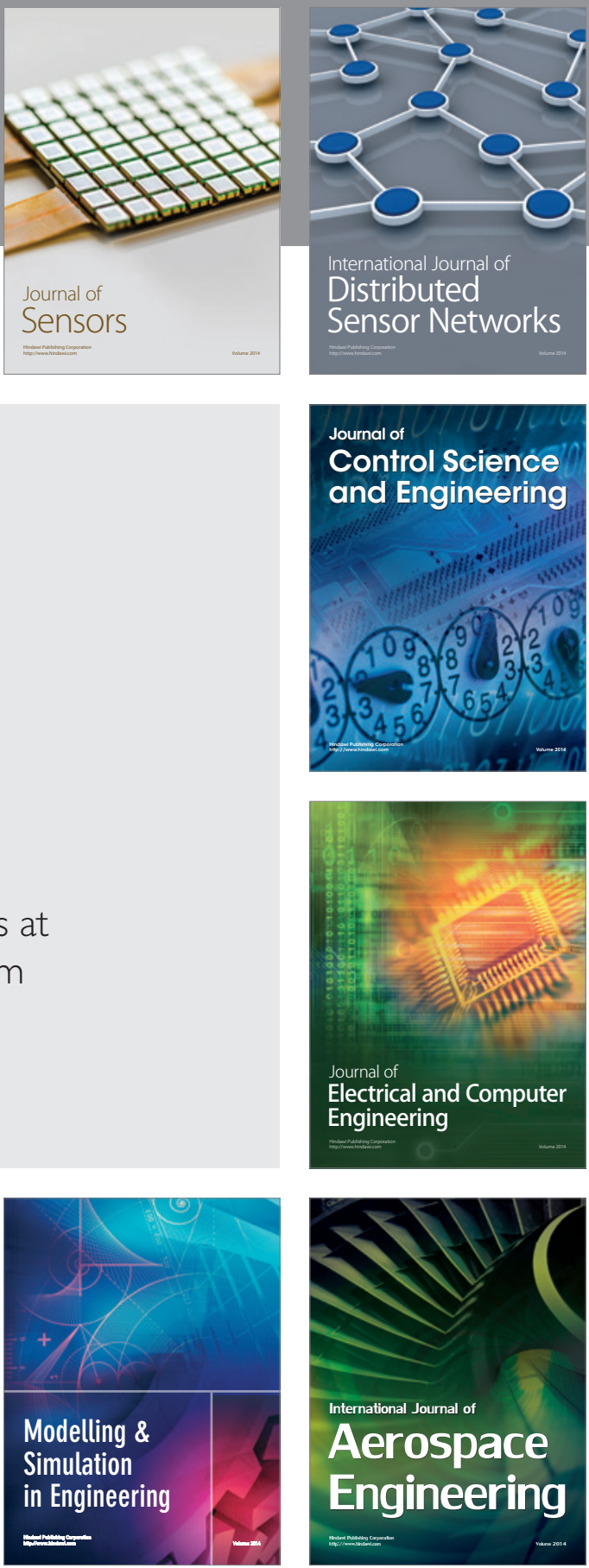

Journal of

Control Science

and Engineering
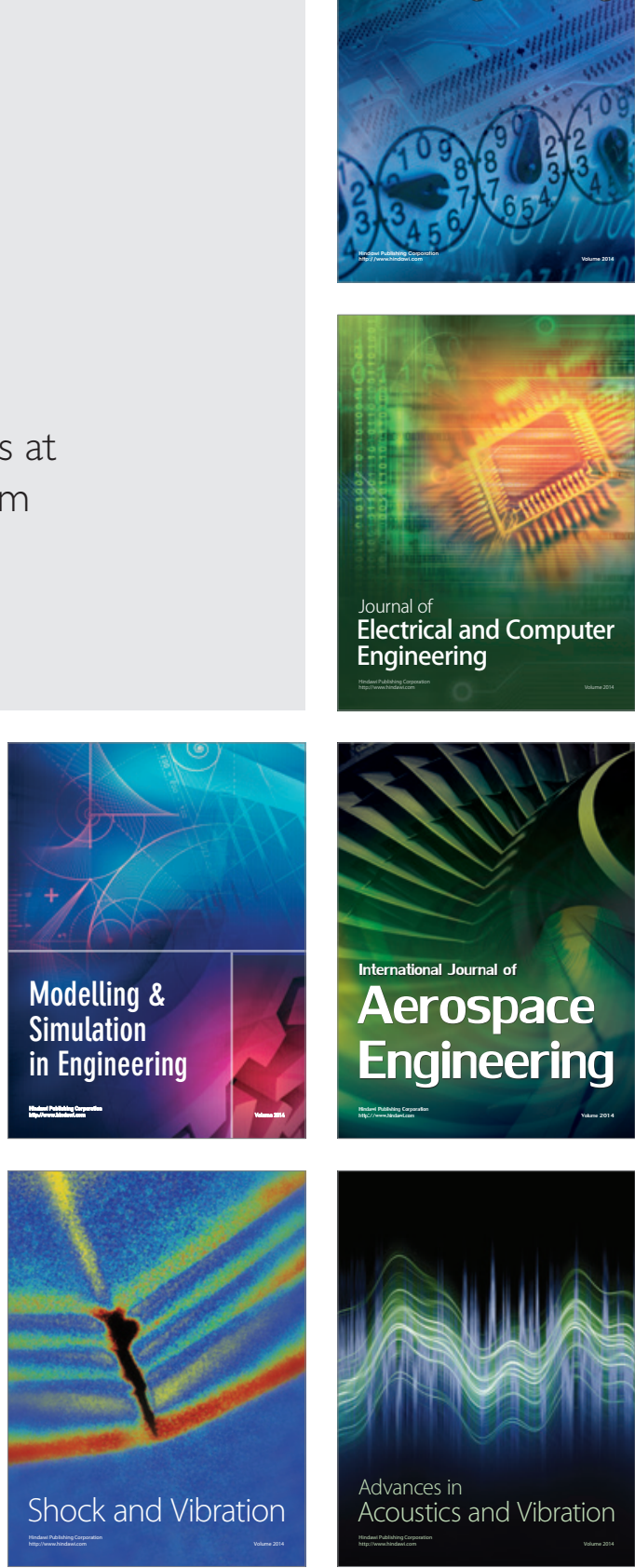